\title{
Description of a new species of Gaeolaelaps (Acari: Laelapidae) from Iran
}

\author{
Zarir Saeidi', Alireza Nemati², Arsalan Khalili-Moghadam² \\ I Department of Plant Protection, Agricultural and Natural Resources Research and Education Center, Cha- \\ harmahal va Bakhtiari, Iran 2 Plant Protection Department, Agricultural College, Shahrekord University, \\ Shahrekord, Chaharmahal va Bakhtiari, Iran
}

Corresponding author: Zarir Saeidi (zarirsaeidi@yahoo.com)

Academic editor: Farid Faraji | Received 24 June 2016 | Accepted 6 August 2016 | Published 23 August 2016

http://zoobank.org/40F43676-C973-44C0-A69C-35B40860C7F1

Citation: Saeidi Z, Nemati A, Khalili-Moghadam A (2016) Description of a new species of Gaeolaelaps (Acari: Laelapidae) from Iran. ZooKeys 612: 31-40. doi: 10.3897/zookeys.612.9678

\begin{abstract}
A new species of Gaeolaelaps (Acari, Mesostigmata, Laelapidae), G. izajiensis sp. $\mathbf{n}$. is described based on the morphological characters of adult females which were collected from soil sample in the Izeh and Ghaletol regions of the Khuzestan province, Iran. It can be distinguished from the other members of the genus by some morphological characteristics of dorsal shield, form and reticulation of epigynal shield, the exopodal plates, and the peritremes.
\end{abstract}

\section{Keywords}

Chaetotaxy, Mesostigmata, mite, soil, taxonomy

\section{Introduction}

Mites of the family Laelapidae are ecologically divers and comprise parasites and predators which found in various habitats (Strong and Halliday 1994, Beaulieu 2009, Lindquist et al. 2009, Nemati and Mohseni 2013). They are good candidates for biological control of the pests which spend time in the soil or other plant growing media (Beaulieu 2009). The family increased in the size with around 90 known genera and 
more than 1300 species (Beaulieu et al. 2011). Gaeolaelaps is a large cosmopolitan genus of the Laelapidae family which consists of more than 100 described species (Nemati and Mohseni 2013, Kazemi et al. 2014). Different types of the habitats were reported for the Gaeolaelaps mites including: soil, litter, nests and bodies of vertebrates and invertebrates (Bregetova 1977, Beaulieu 2009, Lindquist et al. 2009, Trach 2012). Gaeolaelaps species are typically known as small invertebrate predators, and collected from the bodies and nests of many arthropods including cockroaches, termites, mole crickets, beetles, ants, millipedes and mygalomorph spiders (Bregetova 1977, Rosario 1981, Tenorio 1982, Strong and Halliday 1994, Fain et al. 1995, Strong 1995, Beaulieu 2009, Faraji and Halliday 2009).

Twenty species of Gaeolaelaps have been reported from Iran of which nine were described as new for science (Nemati and Kavianpour 2013, Nemati and Mohseni 2013, Kavianpour et al. 2013, Kazemi et al. 2014, Kavianpour and Nemati 2014, Vatankhah et al. 2016). It is noticeable that the majority of these species (seven species) have been collected from soil (Nemati and Kavianpour 2013, Nemati and Mohseni 2013, Kavianpour et al. 2013, Kazemi et al. 2014, Kavianpour and Nemati 2014), one species (Vatankhah et al. 2016) has been described from the nest of Formica sp. (Hymenoptera: Formicidae) and one species from the body of a carabid beetle, Acinopus sp. (Coleoptera: Carabidae) which the later had been previously excluded from Gaeolaelaps by Kazemi et al. (2014). Four of these species including G. farajii Nemati \& Mohseni, 2013; G. jondishapouri Nemati \& Kavianpour, 2013; G. khajooii Kazemi, Rajaei \& Beaulieu, 2014 and G. orbiculatus Nemati \& Mohseni, 2013 were reported from the south of Iran (Khuzestan and Kerman provinces) while one species ( $G$. ahangarani Kazemi \& Beaulieu, 2014) has been described from the north (Mazandaran province) and three species (G. iranicus Kavianpour \& Nemati, 2013, G. mossadeghi Kavianpour \& Nemati, 2013 and G. lenis Vatankhah \& Nemati, 2016) from the central part of Iran (Esfahan province). Here a further new species is described, which will be the tenth species from Iran; it was collected from the soils of Izeh and Ghaletol, Khuzestan province, Iran.

\section{Materials and methods}

Gaeolaelaps specimens were extracted from soil samples using Berlese funnels, placed in lactic acid at $55^{\circ} \mathrm{C}$ for clearing and then mounted in Hoyer's medium as permanent microslides for microscopic examination. Taxonomically relevant structures of this species were illustrated with the use of a drawing tube and figures were performed with Corel X-draw software, based on the scanned line drawings. Measurements of structures are expressed as minimum-maximum ranges in micrometers. The dorsal setae notation, leg and palp chaetotaxy follows that of Lindquist and Evans (1965), Evans (1963a, b) and Evans and Till 1965 respectively. Terminology for idiosomal glands and lyrifissures follows Kazemi et al. (2014). Legs were measured dorso-medially excluding the stalk and pretarsus. 


\section{Reults}

\section{Genus Gaeolaelaps Evans \& Till, 1966}

Hypoaspis (Gaeolaelaps) Evans \& Till, 1966: 160; Evans and Till 1979: 202.

Hypoaspis (Geolaelaps): Bregetova 1977: 499; Karg 1979: 79; Karg 1982: 237; Karg 1993: 136.

Gaeolaelaps: Casanueva 1993: 40; Beaulieu 2009: 35; Kazemi et al. 2014: 504.

Geolaelaps: Rosario 1981: 46; Walter and Oliver 1989: 295.

Type species. Laelaps aculeifer Canestrini (1884), by original designation (Evans and Till 1966).

The genus definition of Kazemi et al. 2014 was followed (see notes in discussion).

\section{Gaeolaelaps izajiensis sp. n.}

http://zoobank.org/F8E6016A-33DA-4B04-97FB-67092192A3A9

Figures 1-13

Specimens examined and type deposition. Holotype female, Izeh, Khuzestan province, soil, coll. A. Nemati, 2013. Paratypes: two females, Ghaletol, Khuzestan province, soil, coll. Z. Saeidi, 2014. The holotype and two female paratypes are deposited in the Acarological Laboratory, Department of Plant Protection, Agricultural College, Shahrekord University, Shahrekord, Iran (APAS).

Diagnosis (adult female). Dorsal shield with constriction at lateral margins near setae $s 6$ and distinct reticulation posterior to $j 6$ along with line reticulation in lateral margins of podonotal part, possesses 39 pairs of simple thin acicular setae; sternal shield with reticulation in lateral regions, epigynal shield with elongate and nearly quadrangle cells and abutting anal shield, exopodal plates fragmented between coxae II and IV; peritremes relatively long and extending to the posterior margin of coxae I.

Description of adult female. Three specimens measured, range is provided in $\mu \mathrm{m}$.

Dorsal idiosoma. Idiosoma oval-shaped 431-442 long, 266-273 wide (at level of setae $r 3$ ), dorsal shield with constriction at lateral margins near $s 6$ setae and distinct reticulation posterior to $j 6$ along with line reticulation in lateral margins of podonotal part, shield not covering whole dorsum (Fig. 1), 400-419 long from its anteromedian edge anterior to bases of setae $j 1$ to its posteromedian edge posterior to bases of setae Z5, 240-247 wide at level of setae $r 2-r 3$ (widest part), shield with 39 pairs of thin, small, simple acicular setae, 22 pairs on podonotal region $(j 1-6 ; z 1-6$; $s 1-6$; $r 2-5)$ and 17 pairs on opisthonotal part $(J 1-5 ; Z 1-5$; S1-5) including $P X 2-3$ between $J$ and $Z$ series. Unsclerotised cuticle lateral of podonotal region including a smooth sub-triangular accessory shield (Fig. 1). Dorsal setae short (22-30), not reaching to following seta base in series. Setae J3 located nearly far from J4, the distance of J3-J4 is approximately five times $J 3$ length. Unsclerotised cuticle lateral of podonotal part with 


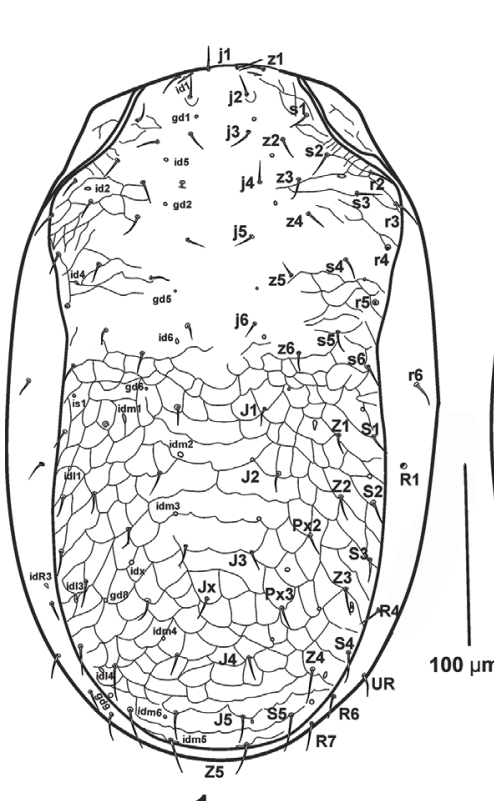

1

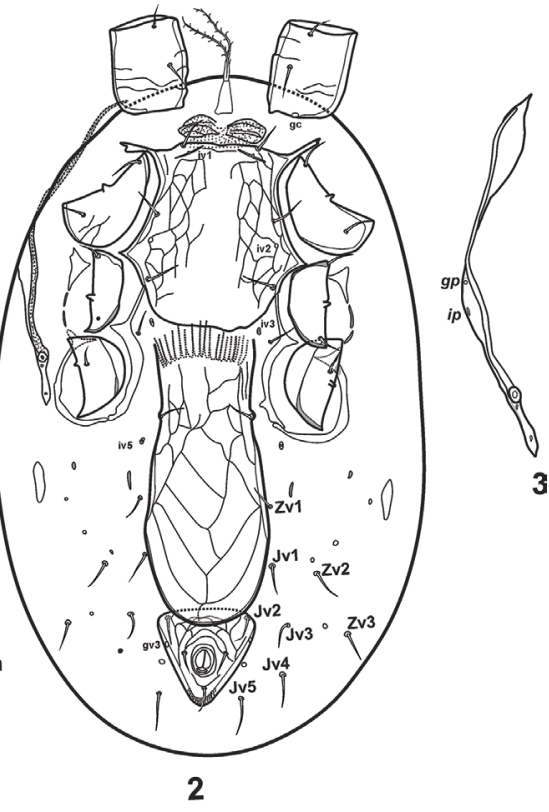

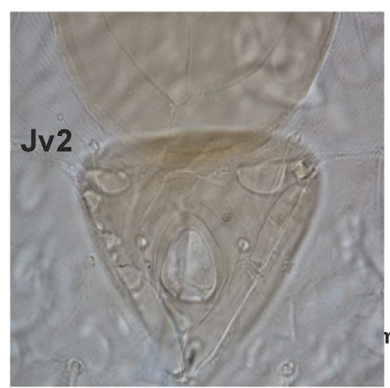

4

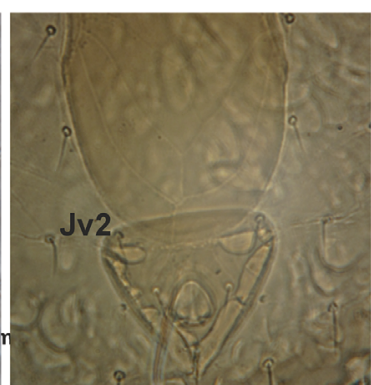

5

Figures I-5. Gaeolaelaps izajiensis sp. n. Female: I dorsal idiosoma $\mathbf{2}$ ventral idiosoma $\mathbf{3}$ Peritreme and sub-triangular accessory shield 4-5 the position of $J v 2$.

$r 6$ (between $s 6$ and $S 1$ ) and lateral of opisthonotal with $R 1, R 4, R 6$ and $R 7$. UR seta located between $R 4$ and $R 6$. Dorsal shield with 22 pairs of pores and pore-like structures, including $g d 2$ (posterolaterad of setae $j 4$ ) and $g d \sigma$ (posterior of $z \sigma$ ) and one pair of poroids (idR3) on soft lateral cuticle near $R 4$ seta as shown in Figure 1.

Ventral idiosoma (Fig. 2). Base of tritosternum 25-30 long, 7-10 wide (at basal level), pilose laciniae free for 59-73 and fused basally for 7-9. Pre-endopodal area granulated, with a pair of slightly sclerotised pre-sternal plates. Sternal shield 120-127 long (along midline from anterior edge to its posterior margin), 98-110 wide (at level of projection between coxae II-III) and 81-88 at level of st2, smooth in median region and posterior part and reticulated in lateral margins, with distinct anterior and posterior margins, posterior margin irregular. Sternal setae smooth, st1- st3 (20-23), iv1 slit-like, located slightly behind $s t 1$, iv2 pore-like, between $s t 2-s t 3$. Setae $s t 4$ (16-19) and pore-like iv3 located on integument behind posterior margin of sternal shield. 

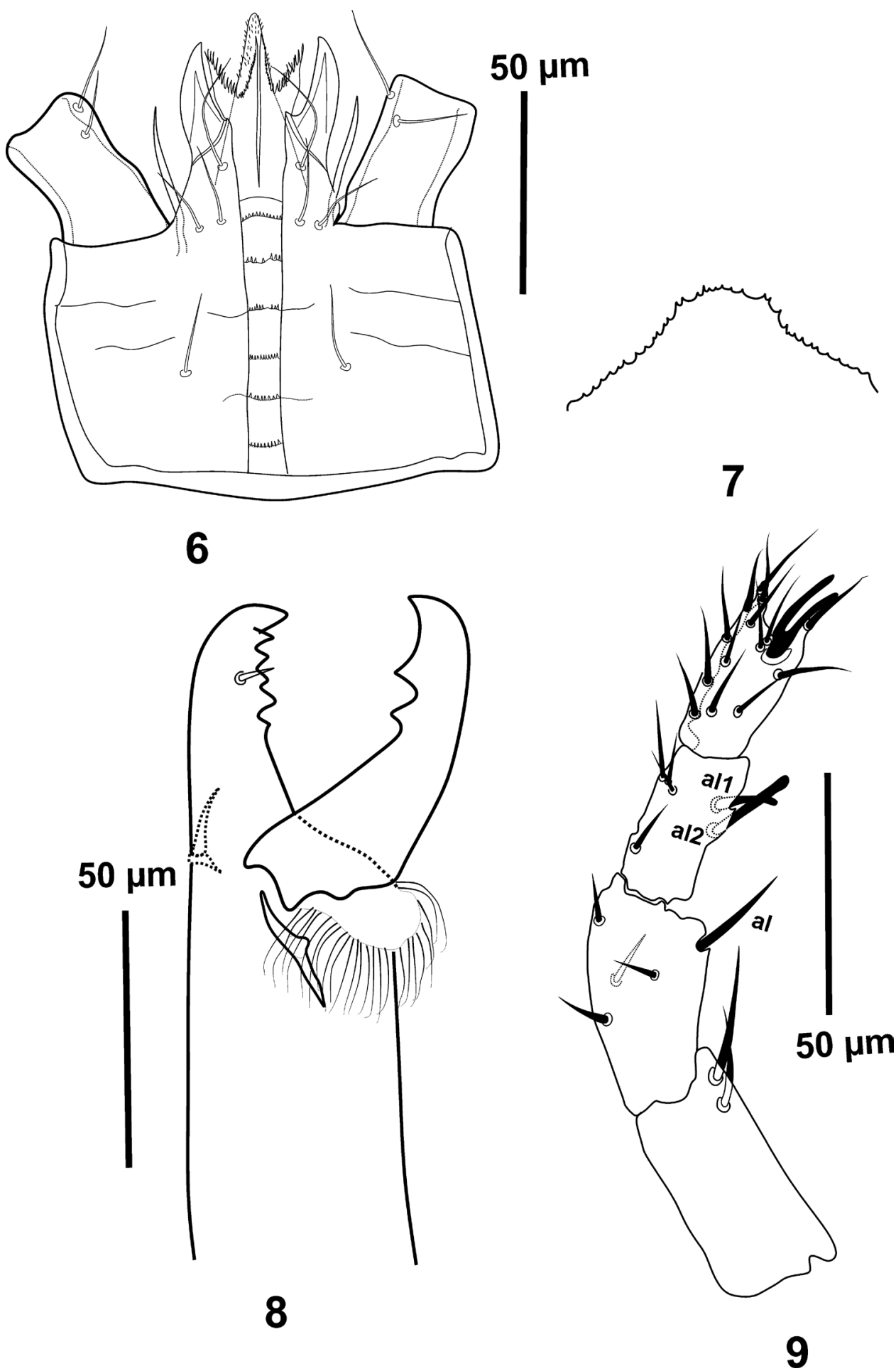

Figures 6-9. Gaeolaelaps izajiensis sp. n. Female: $\mathbf{6}$ hypostome $\mathbf{7}$ epistome 8 chelicera $\mathbf{9}$ palp (trochanter to tibia). 

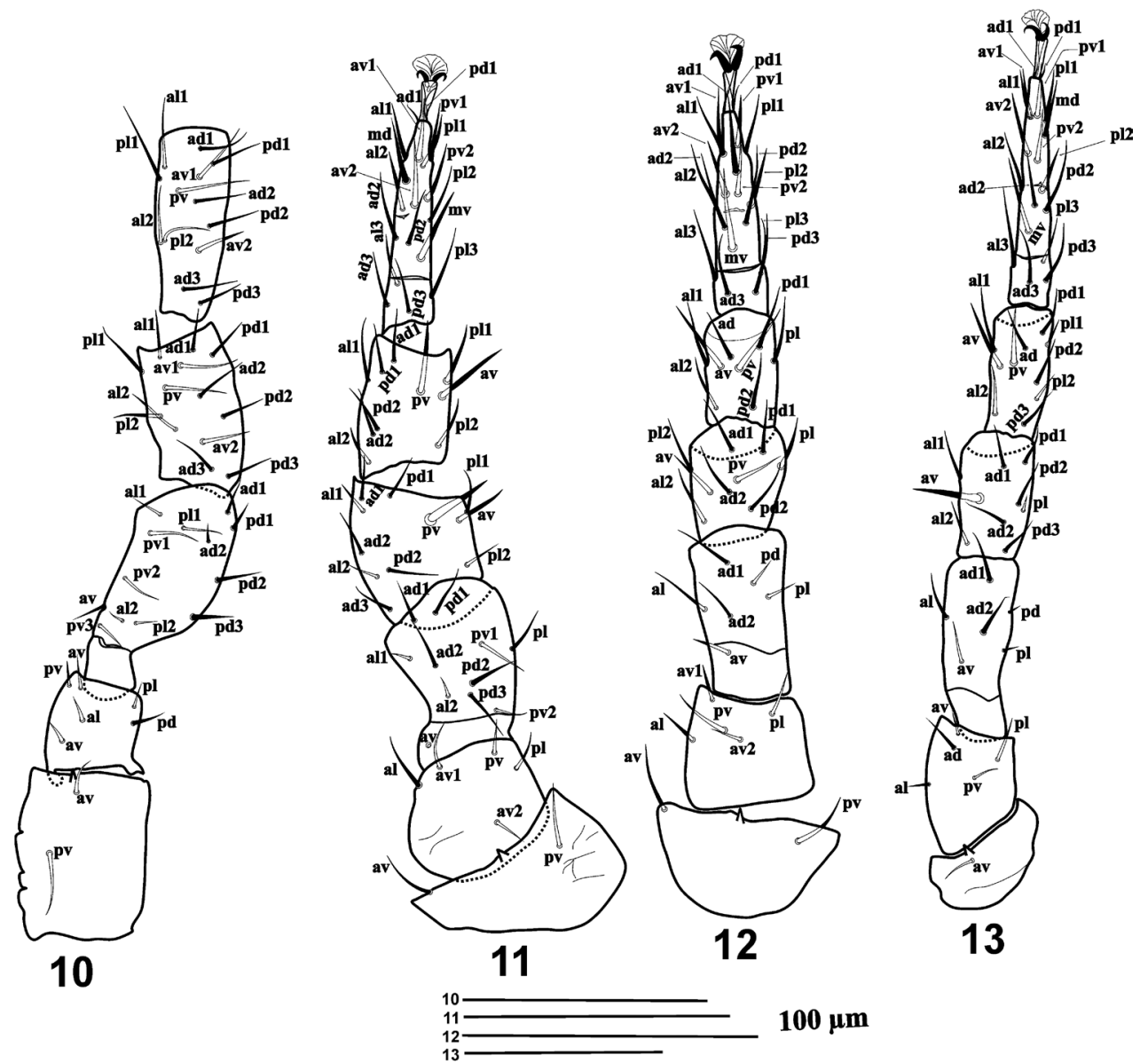

Figures 10-13. Gaeolaelaps izajiensis sp. n. Female: 10 Leg I I I Leg II 12 Leg III 13 Leg IV.

Reticulate tongue-shaped epigynal shield with elongate and nearly quadrangle cells, 171-180 long at midline from anterior margin to posterior level and abutting anal shield, 73-83 wide at epigynal setae, ratio of length to width (L/W) 2.14-2.4, with one pair of simple acicular setae $(s t 5=18-20)$. Paragenital pores (iv5) on soft integument posterior to epigynal setae, between epigynal margin and coxa IV. Anal shield subtriangular, reticulated, 54-60 long (at midline from the anterior margin to the posterior edge of the cribrum), 54-56 wide (at widest point), post anal seta (14-15) nearly equal to para-anal setae (15-17). Cribrum thin and extending posterolaterally to the level of post-anal seta insertion. Opisthogastric surface with: one pair of narrow and slightly elongate paragenital platelets; one pair of suboval metapodal plates (24$26 \times 10-12$ ); one pair of minute platelets between paragenital and metapodal plates; eight pairs of smooth acicular setae: $Z v 1-3$ and $J v 1-5$; and five pairs of pore-like structures, plus para-anal gland pores gv3 on lateral margins of anal shield. Jv2 located on soft opisthogastric cuticle at postero-lateral part of epigynal shield (Fig. 4). In holotype this part of soft cuticle bent down and $J v 2$ appeared on anterior margin of anal shield 
as shown in Figures 2 and 5. Stigma located at anterior level of coxa IV. Peritremes narrow and long, extending anteriorly to posterior margin of coxae I with fusing at posterior margin of sub-triangular accessory shield, peritrematal plate wider in middle part, and with one glandular poroid $g p$ and one lyrifissure ip (Fig. 3), separated from exopodal shield. Poststigmatal plate narrow and with two pore-like structures. Exopodal II-III small and subtriangular, along with two fragmented platelets at posterior part of coxa III. Exopodal III-IV narrow, angular and reached to the tip of endopodal III-IV at posterior level of coxa IV. Endopodal plates II/III incorporated to lateral margins of sternal shield, III-IV strip like extending to the posterior margin of coxa IV.

Gnathosoma. Hypostome (Fig. 6) with three pairs of smooth simple acicular setae; $h 1$ (28-32), h2 (15-17) and h3 (17-19). Palpcoxal setae 17-19 long. Deutosternal groove with six rows of denticles (7-12). Corniculi horn-like, internal malae with median barbed extensions longer than fringed lateral lobes, labrum short and slightly pubescent. Epistome denticulate (Fig. 7). Chelicera (Fig. 8) with dorsal seta, small and setaceous pilus dentilis, lateral lyrifissure and arthrodial crownet-shaped, moveable digit (46-54) with two teeth; middle article from the basal level to the base of dorsal seta 78-85 ending in fixed digit (49-51) with five teeth in addition to terminal tooth. Palp chaetotaxy normal for Laelapidae mites (sensu Evans \& Till, 1965), with simple setae except al1 and al2 of genu slightly thickened with blunt tip, palp apotele two-tined (Fig. 9).

Legs. Tarsi I-IV with claws and ambulacra. leg I 427-432, coxa 61-63, trochanter 39-44, basi-femur 20-24, telo-femur 61-68, genu 66-73, tibia 78, tarsus 90-95; leg II 317-329, coxa 37-39, trochanter 41-44, basi-femur 17-22, telo-femur 49-56, genu 46-54, tibia 46-49, tarsus: 73-78; leg III 249-259, coxa 22, trochanter 37-41, basi-femur 15-20, telo-femur 39, genu 24-32, tibia 37-41, tarsus 63-73; leg IV 383-417, coxa 34-37, trochanter 68-73, basi-femur 20-26, telo-femur 54-61, genu 49-56, tibia 54-61, tarsus 98-103. Legs I and IV longer than legs II and III. Chaetotaxy of all leg segments normal for Gaeolaelaps (sensu Faraji \& Halliday, 2009). All leg setae smooth and pointed.

Legs Chaetotaxy (Figs. 10-13): Leg I (Fig. 10): coxa 0 0/1 0/1 0; trochanter $10 / 2$ 1/1 1; femur 2 2/ 3/3 2; genu 2 3/2 3/1 2; tibia $23 / 2$ 3/1 2. Leg II (Fig. 11): coxa 0 0/1 0/1 0; trochanter $10 / 2$ 0/1 1 ; femur $23 / 12 / 21$; genu $23 / 12 / 12$ (pv slightly thicker than other setae on the segment); tibia $22 / 12 / 12$ ( $a v$ and $p v$ slightly thicker than other setae on the segment); tarsus $33 / 23 / 23+m v$, md (pl1, al1, pv1-2, av1-2, $m d$ and $m v$ slightly thicker than other setae on the segment). Leg III (Fig. 12): coxa 0 0/1 0/1 0; trochanter $10 / 20 / 11$; femur $12 / 11 / 01$; genu 2 2/1 2/1 1 ; tibia $21 / 1$ $2 / 11$; tarsus $33 / 23 / 23+m v$, md (the thickness of setae similar to those on tarsus II). Leg IV (Fig. 13): coxa 0 0/1 0/0 0; trochanter $10 / 2$ 0/1 1; femur 1 2/1 1/0 1; genu 2 2/1 3/0 1 (av thicker than other setae on segment); tibia 2 1/1 3/1 2 (av and pv slightly thicker than other setae on the segment); tarsus $33 / 23 / 23+m v$, md (av1-2, pv1-2, $p l 2, m v$ and $m d$ slightly thicker than other setae on the segment. All setae fine and needle-like unless otherwise noted.

Insemination structures. Not seen.

Male. Unknown.

Etymology. The name of the new species refers to Izaj, the ancient name of Izeh (a town in Khuzestan province, southwest Iran) where the holotype was collected. 
Remarks. Gaeolaelaps izajiensis sp. n. is differentiated from all other members of the genus by the following combination of characters: dorsal shield with constriction at lateral margins near setae s6, with 39 pairs of simple thin acicular setae; reticulated epigynal shield with elongate and nearly quadrangle cells and abutting anal shield, exopodal plates fragmented between coxae III and IV; peritremes long and extending to the posterior margin of coxae I. Some species of Gaeolaelaps genus have long epigynal shield like: G. loksai (Karg, 2000), G. pinnae (Karg, 1987) and G. macra (Karg, 1978) in which the epigynal shield extending near anal shield with only one pair of opisthogastric setae between epigynal and anal shields. Gaeolaelaps macra and G. loksai have short peritremes which extended to near anterior and middle level of coxa II, respectively. Gaeolaelaps pinnae has long peritreme extending to anterior part of coxa I but has long dorsal setae which exceed the base of successive setae in series, seta $J 1$ and some other opisthonotal setae barbed distally and iv2 slit-like (Karg 1978, 1987, 2000).

\section{Discussion}

Gaeolaelaps has been defined in details by Beaulieu (2009) and Kazemi et al. (2014). The new species described in this paper is well accordance with definition of Kazemi et al. (2014) except for the characteristic no. 10 (p. 504). They stated that epigynal shield tongue or flask-shaped, not markedly broadened posteriorly, bearing one pair of simple setae, and not touching anal shield.

In some species of this genus (G. loksai (Karg), G. pinnae (Karg) and G. macra (Karg)) epigynal shield extending near subtriangular anal shield in which there is only one pair of opisthogastric setae between these two shields, but in fact none of Gaeolaelaps species has epigynal shield abutting subtriangular anal shield. Our new species has epigynal shield uniquely long and extended to the anal plate with one pair of setae $(J v 2)$ located at posterior latero-corners of epigynal shield on unsclerotised cuticle of opisthogasteric area. In this paper, we have followed the definition of Kazemi et al. (2014) to consider our new species as a member of Gaeolaelaps with the following modification to the no. 10 characteristic (length of epigynal shield):

10. Epigynal shield tongue- or flask-shaped, not markedly broadened posteriorly, bearing one pair of simple setae, and not touching anal shield in most of the species except for G. izajiensis n. sp.

\section{Acknowledgement}

This study was supported by Shahrekord University (Grant no. 94GRD1M1969) and Agricultural and Natural Resources Research and Education Center, Chaharmahal va Bakhtiari, Iran, which is greatly appreciated. The authors wish to thank Dr. Farid Faraji, Dr. Bruce Halliday and Dr. Shahrooz Kazemi for their valuable and constructive suggestions. 


\section{References}

Beaulieu F (2009) Review of the mite genus Gaeolaelaps Evans and Till (Acari: Laelapidae) and description of a new species from North America, G. gillespiei n. sp. Zootaxa 2158: 33-49.

Beaulieu F, Dowling APG, Klompen H, de Moraes GJ, Walter DE (2011) Superorder Parasitiformes Reuter, 1909. In: Zhang Z-Q (Ed.) Animal Biodiversity: An Outline of HigherLevel Classification and Survey of Taxonomic Richness. Zootaxa 3148: 1-237.

Bregetova NG (1977) Family Laelaptidae Berlese, 1892. In: Ghilyarov MS, Bregetova NG (Eds) Key to the Soil Inhabiting Mites. Mesostigmata, Nauka, Leningrad, 483-554. [In Russian]

Casanueva ME (1993) Phylogenetic studies of the free-living and arthropod associated Laelapidae (Acari: Mesostigmata). Gayana Zoologia 57: 21-46.

Evans GO (1963a) Observations on the chaetotaxy of the legs in the free-living Gamasina (Acari: Mesostigmata). Bulletin of the British Museum (Natural History) Zoology 10(5): 277-303.

Evans GO (1963b) Some observations on the chaetotaxy of the pedipalps in the Mesostigmata (Acari). Annals and Magazine of Natural History 13(6): 513-527. doi: $10.1080 / 00222936308651393$

Evans GO, Till WM (1965) Studies on the British Dermanyssidae (Acari: Mesostigmata). Part

1. External morphology. Bulletin of the British Museum (Natural History) Zoology 13: 247-294. doi: 10.5962/bhl.part.16752

Evans GO, Till WM (1966) Studies on the British Dermanyssidae (Acari: Mesostigmata). Part II. Classification. Bulletin of the British Museum (Natural History) Zoology 14: 107-370.

Evans GO, Till WM (1979) Mesostigmatic mites of Britain and Ireland (Chelicerata: AcariParasitiformes), An introduction to their external morphology and classification. Transactions of the Zoological Society of London 35: 139-270. doi: 10.1111/j.1096-3642.1979. tb00059.x

Fain A, Noti MI, Dufrêne M (1995) Observation on the mites (Acari) associated with Carabidae (Coleoptera) in Belgium. I. Annotated list of the species. International Journal of Acarology 21(2): 107-122. doi: 10.1080/01647959508684051

Faraji F, Halliday B (2009) Five new species of mites (Acari: Laelapidae) associated with large Australian cockroaches (Blattodea: Blaberidae). International Journal of Acarology 35(3): 245-264. doi: 10.1080/01647950903059445

Karg W (1978) Zur kenntnis der Milbengattungen Hypoaspis, Androlaelaps and Reticulolaelaps (Acarina, Parasitiformes, Dermanyssidae). Zoologische Jahrbücher Abteilung für Systematik Ökologie und Geographie der Tiere 105: 1-32.

Karg W (1979) Die Gattung Hypoaspis Canestrini 1884 (Acarina, Parasitiformes). Zoologische Jahrbücher Abteilung für Systematik Ökologie und Geographie der Tiere 106: 65-104.

Karg W (1982) Zur Kenntnis der Raubmilbeng Hypoaspis Canestrini, 1884 (Acarina, Parasitiformes). Mitteilungen aus dem Zoologischen Museum in Berlin 58: 233-256.

Karg W (1987) Neue Raubmilbenarten der Gattung Hypoaspis Canestrini, 1884 (Acarina, Parasitiformes). Zoologische Jahrbücher Abteilung für Systematik Ökologie und Geographie der Tiere 114: 289-302. 
Karg W (1993) Raubmilben der Hypoaspididae, Laelapidae und Phytoseiidae auf dem Galapagos-Archipel (Acarina, Parasitiformes). Mitteilungen aus dem Zoologischen Museum in Berlin 69: 261-284. doi: 10.1002/mmnz.19930690207

Karg W (2000) Zur Systematik der Raubmilbenfamilien Hypoaspididae v. Vitzthum, 1941 und Rhodacaridae Oudemans, 1902 (Acarina, Parasitiformes) mit neuen Arten aus Südund Mittelamerika. Mitteilungen aus dem Museum für Naturkunde in Berlin, Zoologische Reihe 76: 243-262. doi: 10.1002/mmnz.20000760207

Karg W (2006) The systematics of Parasitiformes, especially of Gamasina leach (Acarina), with new species from Ecuador. Mitteilungen aus dem Museum für Naturkunde in Berlin, Zoologische Reihe 82: 140-169. doi: 10.1002/mmnz.200600002

Kavianpour M, Nemati A, Gwiazdowicz D, Kocheili F (2013) A new species of the genus Gaeolaelaps (Acari, Mesostigmata, Laelapidae) from Iran. ZooKeys 277: 1-11. doi: 10.3897/ zookeys.277.4741

Kazemi Sh, Rajaei A, Beaulieu F (2014) Two new species of Gaeolaelaps (Acari: Mesostigmata: Laelapidae) from Iran, with a revised generic concept and notes on significant morphological characters in the genus. Zootaxa 3861(6): 501-530. doi: 10.11646/zootaxa.3861.6.1

Lindquist EE, Evans GO (1965) Taxonomic concepts in the Ascidae, with a modified setal nomenclature for the idiosoma of the Gamasina (Acarina: Mesostigmata). Memoirs of the Entomological Society of Canada 47: 1-64. doi: 10.4039/entm9747fv.

Nemati A, Kavianpour M (2013) A new species of Laelapidae (Acari: Mesostigmata) from Iran. Journal of Crop Protection 2(1): 63-73.

Nemati A, Mohseni M (2013) Two new species of Gaeolaelaps (Acari: Laelapidae) from Iran. Zootaxa 3750(1): 71-82. doi: 10.11646/zootaxa.3750.1.5

Rosario RMT (1981) Philippine Hypoaspidinae (Acarina; Mesostigmata: Laelapidae). Philippine Entomologist 5: 23-82.

Strong KL (1995) A new species of Hypoaspis (Acarina: Laelapidae) associated with funnel-web spiders (Araneae: Hexathelidae). Records of the Western Australian Museum Supplement 52: 219-223.

Strong KL, Halliday RB (1994) Three new species of Hypoaspis Canestrini (Acarina: Laelapidae) associated with large Australian cockroaches. Journal of the Australian Entomological Society 33: 87-96. doi: 10.1111/j.1440-6055.1994.tb00927.x

Tenorio JM (1982) Hypoaspidinae (Acari: Gamasida: Laelapidae) of the Hawaiian Islands. Pacific Insects 24: 259-274.

Trach VA (2012) Gaeolaelaps carabidophilus n. sp., a new mite species (Acari: Mesostigmata: Laelapidae) from carabid beetles (Coleoptera: Carabidae) from Southern Ukraine. Acarologia 52(2): 157-163. doi: 10.1051/acarologia/20122045

Vatankhah F, Nemati A, Esfandiari M, Shishehbor P (2016) Description of a new species of Gaeolaelaps (Acari: Laelapidae) from Iran, with a key to world species of the genus with short peritremes. Zootaxa 4121(5): 566-574. doi: 10.11646/zootaxa.4121.5.6

Walter DE, Oliver Jr JH (1989) Geolaelaps oreithyiae, n. sp. (Acari: Laelapidae), a thelytokous predator of arthropods and nematodes, and a discussion of clonal reproduction in the Mesostigmata. Acarologia 30: 293-303. 